\title{
Psychosocial Intervention: A Journal's Journey Towards Greater Scientific Quality, Visibility and Internationalization
}

\author{
Psychosocial Intervention: A Jornada de uma Revista Rumo a Qualidade \\ Cientifica, Visibilidade e Internacionalização
}

\author{
Enrique Gracia* \\ Universitat de València, Valencia, Spain
}

\begin{abstract}
This paper describes the journey that the journal Psychosocial Intervention began in 2011, with the aim of increasing its scientific quality and broadening its reach. Founded in 1992, Psychosocial Intervention began a new phase in 2011, with the advent of a new Editor-in-Chief, editorial team, and editorial policy. At that point, strategic decisions were made in the areas of editorial and review practices, language, and dissemination of the journal, which resulted in a publication of higher quality and broader reach. The description of the journey undertaken by Psychosocial Intervention is presented with the hope that this experience may be useful to scholars, scientific organizations, and institutions in the area of psychology that share similar objectives of upgrading the scientific quality of their publications, and broadening their reach.

Keywords: editorial policy, internationalization, journal, Psychosocial Intervention, scientific quality, visibility
\end{abstract}

\begin{abstract}
Resumo
O presente artigo descreverá o percurso que a revista Psychosocial Intervention iniciou em 2011 com o objetivo de aumentar sua qualidade científica, sua visibilidade e sua internacionalização. Embora a revista Psychosocial Intervention tenha sido fundada em 1992, em 2011 a revista iniciou uma nova fase quando um novo redator-chefe foi nomeado, e uma nova equipe e política editoriais foram estabelecidas. O percurso da revista em direção a esses objetivos será descrito através da explicação de um conjunto de decisões estratégicas que foram tomadas nas áreas de práticas e critérios editoriais (qualidade científica), linguagem (manuscritos em Inglês e traduções para o Espanhol), visibilidade e disseminação da revista (sites de revistas e acesso via internet), e base de dados internacionais. A descrição do percurso realizado pela Psychosocial Intervention é feito com a esperança de que sua experiência possa ser útil para acadêmicos, organizações científicas ou instituições na área da psicologia que também compartilham os objetivos de reforçar a qualidade científica de suas publicações e aumentar sua visibilidade e internacionalização.

Palavras-chave: política editorial, internacionalização, periodic, Psychosocial Intervention, qualidade científica, visibilidade
\end{abstract}

The journal Psychosocial Intervention was founded in 1992 by the Colegio Oficial de Psicólogos de Madrid (Spain) in association with the Consejo General de Colegios Oficiales de Psicólogos and the Coordinadora Estatal de Intervención Social. The title of the journal when it was first launched was "Intervención Psicosocial: Revista de igualdad y calidad de vida." In 2011, however, the journal commenced a new phase with the appointment of a new Editor-in-Chief, a complete renewal of the editorial board, and a new editorial scope.

* Correspondence concerning this article should be addressed to Enrique Gracia, Department of Social Psychology, University of Valencia, Avda. Blasco Ibáñez 21, Valencia 46010, Spain; e-mail: enrique.gracia@uv.es
To mark this new phase the journal also changed its title to Psychosocial Intervention, its parallel title in English. To reflect the history of the journal, the front cover of the print edition retains a portion of its original title: Intervención Psicosocial. This new phase of the journal was also marked by a co-publishing arrangement with Elsevier, which has been in place since 2013.

This new phase of Psychosocial Intervention, characterized by the redefinition of the editorial team, had a pair of main objectives: increasing the journal's scientific quality and broadening its reach. This paper will provide an overview of the editorial strategies, changes, and decisions undertaken by the new editorial team who had the aim of improving the scientific quality of the journal's contents, 
Enrique Gracia, E. (2015). An Analysis of the Psychosocial Intervention: A Journal's Journey Towards Greater Scientific Quality, Visibility and Internationalization

raising the international profile of the journal's editorial board and authors, increasing the visibility of the journal to a global readership, and bolstering the journal's presence in international databases. The journey towards these goals will be described by explaining strategic decisions that were undertaken in the areas of editorial practices and criteria, language presentation, dissemination of the journal, and bolstering its presence in international databases (Gracia, 2012).

The description of the journey undertaken by Psychosocial Intervention is made with the hope that this experience may be useful to scholars, scientific organizations, and institutions in the area of psychology that share similar objectives of strengthening the quality of their publications, and broadening their reach.

\section{The New Editorial Phase}

The new editorial phase of Psychosocial Intervention began in 2011 with a new editorial team and a new editorial scope. The main aim was that of increasing the scientific quality of its published papers, and raising the international profile of both its authors and its readers. The first step, and also the first challenge, was gathering the support and commitment of a number of renowned national and international experts in the academic field the journal aimed to represent. These experts comprised the new editorial board, which at present consists of national and international experts from twelve countries, and four continents.

The new editorial line of the journal, supported by the new editorial board is summarized in the new Scope of the Journal:

"Psychosocial Intervention is a peer-reviewed journal that publishes papers in all areas relevant to psychosocial intervention at the individual, family, organizational, community, and population levels. The journal emphasizes an evidence-based perspective and welcomes papers reporting original basic and applied research, program evaluation, and intervention results. The journal will also feature integrative reviews, and specialized papers on theoretical advances and methodological issues. Psychosocial Intervention is committed to advance knowledge, and to provide scientific evidence informing psychosocial interventions tackling social and community problems, and promoting social welfare and quality of life. Psychosocial Intervention welcomes contributions from all areas of psychology and allied disciplines, such as sociology, social work, social epidemiology, and public health. Psychosocial Intervention aims to be international in scope, and will publish papers both in Spanish and English."

The configuration of the new editorial board and the reformulation of the journal's scope was the first and necessary step of beginning a new phase in which greater scientific quality, visibility, and internationalization of contents were the main objectives. However, to reach these objectives, a wider set of strategies in a number of areas of editorial policy was also needed. These new strategies embodied: language of the manuscripts, visibility and dissemination of the journal and its contents, policing and monitoring of open access archives, and inclusion in international databases. These strategies are now described.

\section{Ensuring Scientific Quality}

To ensure the scientific quality of a journal a set of basic standards in editorial practices are needed. Although these standards can vary depending on the scientific area, there are elements consistent among almost all scientific publications. These standards for scientific editing are a prerequisite for a journal to be included in databases that endorse the quality of scientific publications (see below, section on databases and indexing systems). However, each one of these databases has its own requirements for inclusion. For journal editors/publishers, it is advisable to learn about these requirements, especially if your goal is to submit a publication for evaluation by those terms. For inclusion on such high-profile, international, databases such as Web of Knowledge or Scopus, it is critical that the editorial practices meet their criteria (see, for example, Rew, 2013; Testa, 2012).

In the new phase of Psychosocial Intervention, the editorial team was aware of the importance of these basic editorial standards, and the editorial process was adapted to meet them. Although these standards are well known, and can be viewed in the inclusion requirements of the main scientific databases/indexing systems (see, for example, the selection criteria on the Scopus, WOK, or PsycINFO websites), we shall summarize them briefly here. These requirements are a first and fundamental step in providing a solid basis for a journal's scientific quality. In addition, they facilitate the journal's recognition by scientific databases and indexing systems. Among these basic editorial practices are (Gracia, 2012):

\section{Timely Publication}

The regularity with which a scientific journal is published tends to be a prerequisite for the evaluation of the quality of a journal, because it is an indicator of whether a publication has sufficient volume of scientific contributions to endorse its viability. For example, since Psychosocial Intervention started its new editorial phase the journal has consistently published with the established frequency.

\section{Peer Review}

This is another basic prerequisite that indicates the scientific quality of a journal, because reviews by experts (who are usually anonymous) ensure that contributions published by the journal are original, up-to-date, and of quality. With regard to peer review, Psychosocial Intervention follows a double-blind peer review process. 


\section{Bibliographical Information in English}

Most databases ask for, at least, the titles, abstracts and keywords to be translated into English. In addition to this, another important indicator of the internationalization of the journal is the publication of full texts in English. Psychosocial Intervention has a broad international representation and, since it started its new phase, has significantly increased the internationalization of its contributors. The journal currently publishes around $50 \%$ of its original articles in English (see below for further information on the language policy of the journal).

\section{International Diversity}

This is an important aspect emphasized by the more important scientific databases such as Web of Knowledge or Scopus. The international diversity of authors, editors and members of the Editorial Boards is considered an important indicator of a journal's internationalization.

\section{Ethical Standards}

It is also important for journals to ensure that their contributions comply with the ethical standards related to their area of knowledge. Psychosocial Intervention, for example, a journal where most of its contributions come from psychology, adopts the recommendations of the American Psychological Association (APA), whereby authors must verify compliance with its ethical standards, and its regulations for the presentation of research results. Authors are also responsible for revealing possible conflicts of interest. In addition to complying with APA recommendations, the journal is also a member of, and subscribes to the principles of, the Committee on Publication Ethics (COPE).

\section{Originality and Scientific Content}

Most databases and indexing systems for scientific journals require that a high percentage of journal contributions present results of empirical studies conducted by the authors, as well as studies from the academic world. These two areas are hallmark to the top-tiered research journals.

\section{Language Presentation}

Among the important decisions that the editors of Psychosocial Intervention made was to broaden readership through bi-lingual publication. Starting in 2011, the publication began to publish manuscripts in both English and in Spanish. The objective of this phase, apart from increasing readership in Spanish-speaking areas, was to reach a wider international audience with the increase of manuscripts in English. One challenge of this international expansion was to not alienate readers who only read in Spanish. Mindful of this, in 2011, the journal began to offer a Spanish translation (available online) of articles originally in English. Thus, for the first time, readers with a low level of proficiency in English had access to quality English-language research; while English-language authors had at their disposal the means to reach a wider Spanish-language audience. This win-win situation increased the journal's reach and motivated English-language authors to contribute. As a measure of this success, since the publication's new phase (vol. 20, year 2011), virtually half of the manuscripts the journal puts in press are Englishlanguage contributions.

Most issues of Psychosocial Intervention showcase original manuscripts in Spanish and in English. However, an indicator of the growing importance of Englishlanguage publication can be found in the number of special issues published, comprised exclusively of articles from English-language authors. Since 2011, Psychosocial Intervention has published the following special Englishlanguage issues:

- Psychosocial studies of migration and community (Perkings, Palmer, \& García-Ramírez, 2011).

- Evidence-based programs for children, youth, and families: Lessons from outcomes and cost-benefits evaluation (de Paúl, 2012).

- Out of home care in child protection: An international overview (del Valle, 2013).

- Community psychology contributions to the study of social inequalities, well-being and social justice (García-Ramírez, Balcázar, \& de Freitas, 2014).

Related to international authorship, an analysis of all contributing authors to the journal since 2011 revealed that the distribution of international vs. Spanish authorship was nearly 50\%, with 116 Spanish authors, and 102 nonSpanish authors. Although non-Spanish authors are from a variety of countries, including other European, Latin American, and Anglo-Saxon countries, the second largest main contributor to the journal in number of authors is the US, followed by authors from other European countries, and Spanish-speaking countries other than Spain.

\section{Internationalization through the Internet}

A key strategy in the journey of Psychosocial Intervention as it moved towards higher visibility was the upgrading of its website. The goal was to gear content to a wider audience, both nationally and internationally.

It is important to point out that until 2010 the journal was hosted at the website of the Colegio Oficial de Psicólogos Madrid (the publisher of the journal), in a web space that included other publications of this group. Although a website was available, the journal lacked a domain of its own. The new editorial team decided, therefore, to create a new website for the journal, with its own, unique domain. This was considered necessary for the journal, because having its own domain would raise its presence on the Internet, through such search engines as Google and Yahoo! 
Enrique Gracia, E. (2015). An Analysis of the Psychosocial Intervention: A Journal's Journey Towards Greater Scientific Quality, Visibility and Internationalization

The new policy concerning language (see above) was addressed in the new website. Thus, the site was designed with a bilingual structure, with two parallel menus, one in Spanish and one in English. The journal's metadata (i.e., the information used by the search engines) was also defined in both these languages. This strategy included the generation of a DOI number for each article (also included in the metadata). The DOI number (acronym for Digital Object Identifier) provides an infrastructure for the unique identification and persistent localisation of digital contents. It is also a prerequisite that is increasingly requested by databases and indexing systems (see, for more information: http:// www.doi.org).

The revamped website included titles and abstracts in Spanish and in English for all articles and also, as mentioned earlier, Spanish translations of all articles that first appeared in English. The initial website for this phase of the journal (http://www.psychosocialintervention.org) now hosts the complete archive of the journal's contents since 1992: Intervención Psicosocial through 2010; Psychosocial Intervention from 2011 forward. However, since 2013 Psychosocial Intervention has resided at a new site within the domain of Elsevier, which serves as publisher and co-editor. Psychosocial Intervention's current website, therefore, is: http://www.elsevier.es/psi

This web strategy has proved to be successful. As seen in Figure 1, the number of visits to the journal website has increased dramatically, moving from around 10,000 visits in 2010 to nearly 400,000 in 2013. Table 1 shows the readers' country of origin. Spain remains the main provider of visitors (nearly $43 \%$ ), as it is the country in which the journal is edited. Latin-American countries provide another $40 \%$ of the visitors, as this is an audience with strong cultural and language links with Spain. Web traffic from Anglo-Saxon countries (mainly US and UK) is about $6 \%$, which highlights a remaining challenge for the journal, as this audience appears more difficult to reach. However, the editors hope that with the increasing publication of original English-language papers, they will be soon able to reach more readers from these countries. The journal contents from 2011 onwards are also covered, since 2013, by ScienceDirect, a formidable database which includes almost onequarter of the world's peer-reviewed scientific content. This coverage provides greater international visibility to the journal.

Finally, since 2011, Psychosocial Intervention has published all its content in Open Access format. This has been a strategy to achieve maximum penetration and dissemination of the journal, both at national and international levels.

\section{Databases and Indexing Systems}

The inclusion in a variety of viable databases and indexing systems is another important step in a journal's journey towards greater scientific quality, visibility and internationalization. This is because databases and indexing systems multiply the sources from which readers, researchers, and educational organizations can access a journal's contents. Inclusion in these databases means the journal has met the minimum standards of scientific quality, as mentioned in the text before. This inclusion, therefore, can be seen as a stamp of scientific endorsement; it is a milestone for an up-and-coming journal.

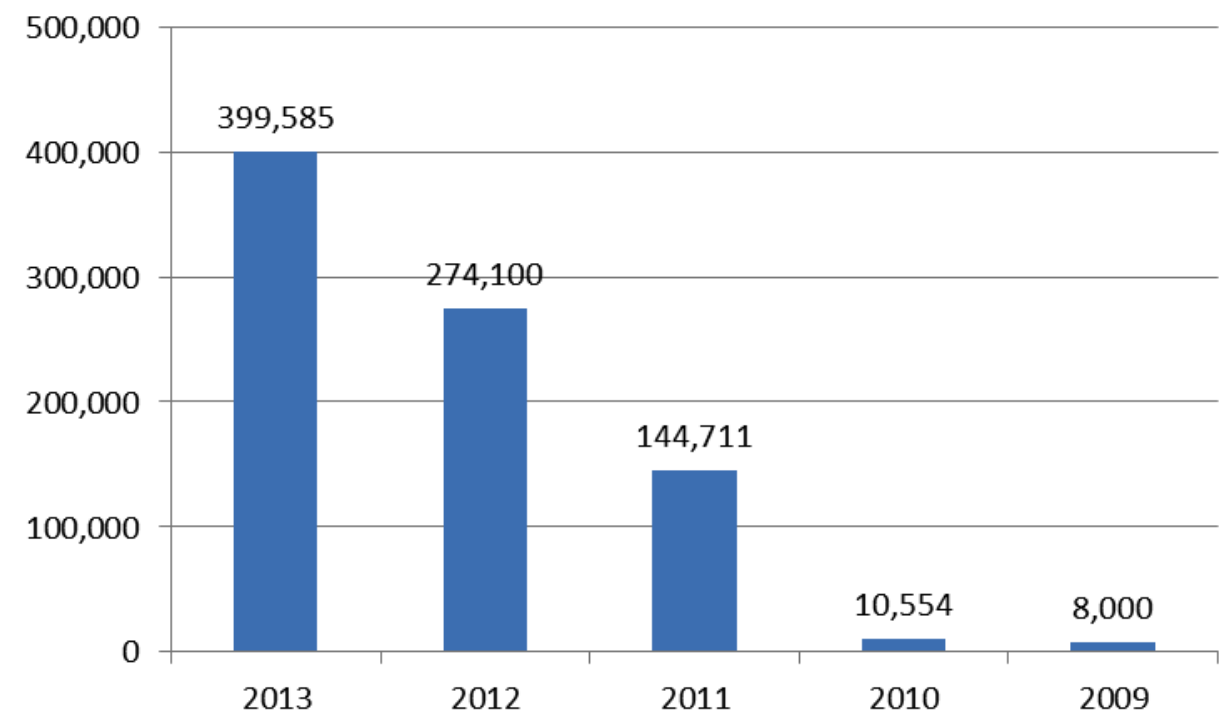

Figure 1. Visitors to Psychosocial Intervention Website: 2009-2013. 
In the case of Psychosocial Intervention, the journal is indexed in the following databases:

- A+ ANECA / Sello de calidad FECYT 2012

- Academic Search Complete (EBSCO)

- DICE \& RESH (CINDOC, CSIC)

- DOAJ (Directory of Open Access Journals)

- Google Académico (Google Scholar)

- IBECS (Biblioteca Nacional de Ciencias de la Salud, España)

- IN-RECS (Índice de Impacto Revistas Españolas de Ciencias Sociales)

- ISOC (CINDOC, CSIC)

- Latindex (América Latina, el Caribe, España y Portugal)

- PsycINFO

- PSICODOC (Colegio Oficial de Psicólogos de Madrid)

- Psyke (Universidad Complutense de Madrid)

- Redalyc (Red de Revistas Científicas de América Latina y El Caribe, España y Portugal)

- ScienceDirect

- Scopus

- Under evaluation by Web of Knowledge (Thomson Reuters), Impact factor expected in 2015.

\section{Closing}

This paper has chronicled the journey of Psychosocial Intervention through a critical developmental stage. It has been a coming-of-age story, of sorts, as the journal set goals for higher quality and wider readership. Did the journal meet its goals? Well, yes. At least according to the data (see Figure 1 and Table 1); but in reality, it has a long way to go (e.g., increasing its $6 \%$ English-language readership). In sharing this process, we hoped that the challenges we faced, and the solutions that we offered, would ring true to fellow scholars, scientific groups and institutions, who are also looking to upgrade their scientific output, and increase their visibility and reach.

Table 1

Visitors to Psychosocial Intervention Website: Countries of Origin

\begin{tabular}{|c|c|}
\hline Country & $\%$ \\
\hline Spain & 42.95 \\
\hline Mexico & 14.33 \\
\hline Colombia & 7.56 \\
\hline Peru & 5.85 \\
\hline Chile & 3.33 \\
\hline US & 3.30 \\
\hline Argentina & 3.21 \\
\hline UK & 2.80 \\
\hline Venezuela & 1.90 \\
\hline Portugal & 1.74 \\
\hline Other & 13.03 \\
\hline
\end{tabular}

\section{References}

American Psychological Association. PsycINFO: journal coverage information for publishers. Retrieved from http:// www.apa.org/pubs/databases/psycinfo/publishers/journals. aspx

American Psychological Association. Ethical principles of psychologists and code of conduct. Standard 8: Research and publication. Retrieved from http://www.apa.org/ethics/code/ index.aspx?item $=11$

Committee on Publication Ethics (COPE). Retrieved from www. publicationethics.org

de Paúl, J. (2012). Evidence-based programs for children, youth and families: Introduction to the special issue. Psychosocial Intervention, 21, 113-115. doi:10.5093/in2012a19

del Valle, J. F. (2013). Out of home care in child protection: An international overview. Psychosocial Intervention, 22, 161162. doi:http://dx.doi.org/10.5093/in2013a19

García-Ramírez, M., Balcázar, F., \& de Freitas, C. (2014). Community psychology contributions to the study of social inequalities, well-being and social justice. Psychosocial Intervention, 23, 79-81. doi:10.1016/j.psi.2014.07.009

Gracia, E. (2012). Psychosocial intervention. In FECYT (Ed.), Manual de buenas prácticas en la edición de revistas cientificas. Madrid: FECYT.

Perkings, D. D., Palmer, N. A., \& García-Ramírez, M. (2011). Psychosocial studies of migration and community: Introduction to the special issue. Psychosocial Intervention, 20, 237-242. doi:10.5093/in2011v20n3a1

Rew, D. (2013). A general introduction to SCOPUS and the work of the content selection and advisory board. Retrieved from http://www.elsevier.com/_data/assets/pdf_file/0009/148824/ general_introduction_csab.pdf

Scopus: content policy and selection. Retrieved from http://www. elsevier.com/online-tools/scopus/content-overview\#contentpolicy-and-selection

Testa, J. (2012). The Thomson Reuters journal selection process. Retrieved from http://wokinfo.com/essays/journal-selectionprocess/

The Editorial Team (2011). Editorial comment: Psychosocial intervention enters a new phase. Psychosocial Intervention, 20,3 . 